\title{
The Determinant Of Stock Return On Property And Real Estate Companies Listed In Indonesia Stock Exchange
}

\author{
M. Firza Alpi ${ }^{1}$, Puja Rizqy Ramadhan ${ }^{2}$, Nasrul Kahfi ${ }^{3}$ and Ilham Ramadhan Nasution ${ }^{4}$ \\ \{m.firzaalpi@umsu.ac.id $\left.{ }^{1}\right\}$ \\ ${ }^{1}$ University of Muhammadiyah Sumatera Utara, Medan, Indonesia \\ ${ }^{2}$ University of Pembangunan Panca Budi, Medan, Indonesia \\ ${ }^{3}$ University of Samudra, Medan, Indonesia \\ ${ }^{4}$ University of Medan Area, Medan, Indonesia
}

\begin{abstract}
The purpose of this study was to determine and analyze the Effect Return On Assets, Earnings Per Share, and Debt To Equity Ratio Return Against Shares Property and Real Estate companies listed in Indonesia Stock Exchange 2012-2016 In the year either partially or simultaneously. The approach used in this study is associative approach. The data used in this research is the company's financial statements Property and Real Estate Listed on the Indonesia Stock Exchange In the year 2012-2016. Independent variables used in this study consisted of Return On Assets, Earnings Per Share and Debt To Equity Ratio is the dependent variable Stock Return. Data analysis techniques used in this research is Multiple Linear Regression, Classical Assumption, $t$ test, $F$ test and coefficient of determination. While processing the data in this study using SPSS software program (Statistics Package For The Social Sciens) 17.00. The results of this study that the partial Return On Asset significant effect on stock price. The Earning Per Share and Debt to Equity Ratio partially no significant effect on stock price. And simultaneously Return On Assets, Earnings Per Share and Debt to Equity Ratio significant influence on Stock Return On Property and Real Estate Company Listed in Indonesia Stock Exchange.
\end{abstract}

Keywords: Return On Assets, Earnings Per Share, Debt to Equity Ratio, Stock Return

\section{Introduction}

The capital market is a place where various parties, especially companies selling stocks and bonds (bond) with the purpose of the sale proceeds will be used as additional funds or fatherly strengthen the company's capital. Meanwhile, according to Joel G. Siegel and Jae K. Shim is a capital markets trading center long-term debt and shares of the company (Fahmi, 2012).

The capital market is said to have an economic function for the market providing facilities or the vehicle that brings the two interests, namely those who have excess funds (investors) and those who need the funds (the party that issued the securities or issuers. With the capital markets, the parties have excess funds can invest these funds in the hope of obtaining yield (return), while the issuer (in this case) can use the funds for investment purposes without having to wait for the availability of funds from operations of the company. the capital market is said to have the function of the financial because it gives the possibility and the opportunity to earn returns for fund owners (investors), according to the characteristics of the selected investments (Syahyunan, 2015).

Investing in the stock market is short-term investments. It diihat of results (return) measured by capital gains. For speculators who like capital gains, capital markets could be an 
interesting place where investor bias buy when prices fall and sell back when the price rises and the difference that they view abnormal returns (abnormal returns) that are then to be calculated benefits. Investments made investors are assumed to always be based on rational considerations so that various types of information necessary for making investment decisions.

For investors there are three predominant financial ratios are used as a reference to the condition of a company's performance, namely liquidity ratio (liquidity ratio), Solvency Ratio (solvability ratio), Profitability ratios (Fahmi, 2014).

\section{Literature Review}

\subsection{Stock Return}

Return is clappers obtained by companies, individuals and institutions of the results of its investments policy. Without the advantages that can be enjoyed from an investment course, investors will not be willing to invest (Fahmi, 2014).

According Syahyunan (2014) Shares (Stock) are securities that shows ownership of a person or entity to a company. That is, if a person buys shares in a company, means he has been included in a company's capital into the total number of shares purchased.

So the return of shares is stock returns or tingakt returns from the investments made. return stock is one of the factors that motivate investors to invest and also a reward for the courage of investors bear the investment risk was doing. Investments can be interpreted simply as an activity placed funds in one or more assets for a certain period with the hope to earn revenue or an increase in the value of investments. The concept of risk is associated with the return, because investors always expect a level appropriate return on any investment risks it faces

According to Fahmi (2014) states that share the benefits for those who have it will gain some benefit as a form of obligations that must be accepted, namely:

1)

2) Receive dividends that will be given at the end of each year.

3) Capital gains, the gains at the time of the sale of shares held back at a more expensive price.

4) Voting rights for shareholders kinds of common stock (common stock).

\subsection{Return On Asset}

According to Fahmi (2014) states that "Return On Investment (ROI) or return on investment, that some other reference this ratio is also written with a return on total assets (ROA). This ratio is the ratio used in the extent of the investments made capable of providing returns as expected ".

According to (Samsul, 2006) Return on Assets (ROA) is the ratio between operating profit / (operating profit) to total assets. Return is defined as operating profit instead of net income. This is because the operating profit derived from the company's normal activities.

According to (Hani, 2014) Return on assets is the ability of the company from the capital invested in the total assets to produce a net profit. Return on assets is a measure of the efficiency of capital usage within a company. Capital is defined as total assets or total investment.

According (Munawir, 2010) states that the amount of return on assets was influenced by two factors, among others:

1) turn Over Operating assets of which the turnover rate of assets used for the operation. 
2) profit Margin, Namely the amount of operating profit expressed in percentage and total net sales. Profit margin measures the profit that can be achieved by companies associated with their sale.

\subsection{Earning Per Share}

According to (Kasmir, no date) Ratio of Earnings Per Share (Earning Per Share) or also known as book value ratio is the ratio to measure management success in achieving profits for shareholders. A low ratio means that management has not managed to satisfy shareholders, in contrast with a high ratio, then shareholder wealth increased in another sense, that the high rate of return.

According (Sinaga, 2014) Earning Per Share is the amount of revenue that was obtained per share. One reason investors buy stocks is to gain dividends, if the value of earnings per share is smaller then the smaller the company the possibility to distribute dividends. It can be said investors will be more interested in stocks that have high earning per share compared to stocks that have a low Earning Per Share. Earning Per Share which tends to lower stock prices down.

Thus it can be concluded that the earning per share is a ratio which indicates the company's ability to make profits and distribute profits made by the company to shareholders. Earning Per Share can be used as an indicator of the value of the company. Earning Per Share is also one way to measure success in achieving benefits for the shareholders in the company.

The factors that affect the Earning Per Share (EPS) according (Harmono, 2009) states that there are several factors that influence the earning per share is as follows:

1) Volume of shares (number of shares) Number of shares that are traded on a particular period. The trading volume also traded all day.

2) Earnings are shareholders based on the number of shares held. This division will reduce retained earnings and cash available to the company, but the distribution of profits to the owners of the shareholders.

3) Interest and Taxes is the ownership of shares in the form of interest as a result of borrowing money. The tax treatment for shareholders can prove an important consideration in determining the value of shares is planned.

\subsection{Debt to Equity Ratio}

According to (Kasmir, no date) Debt to Equity Ratio (DER) is a ratio used to assess the debt for equity. to find this ratio by means the entire debt, debt smoothly with the rest of the equity. This ratio is useful to know the amount of funds provided the borrower (creditors) to the owner of the company. In other words, this ratio for each rupiah own capital is used to guarantee the debt.

According (Sjahrial, 2008) the leverage ratio aims to make the benefits greater than the cost of assets and sources of funds, thus will benefit advantage saham.dan holder useful for analysis, planning and financial control.

Several factors affect the Debt to Equity Ratio (DER), namely:

1) Equity: Equity may affect Debt to Equity Ratio because the company has a net worth (total assets less liabilities) could be used to finance the company in conducting operations to generate profit.

2) Short-term debt: Long-term debt also affect the stability of Debt to Equity Ratio when the company took the option of long-term debt compared to short-term debt, due to long-term debt is a bad influence compared to short-term debt. 
3) Earnings: Earnings influence on Debt to Equity Ratio is because if income increases, the Debt to Equity Ratio will also increase, but if profits decline Debt to Equity Ratio will participate also declined.

\subsection{Conceptual Framework}

The conceptual framework helps explain the relationship between the independent variable on the dependent variable and Return on Assets (ROA) Earning Per Share (EPS), and Debt to Equity Ratio (DER) of the Stock Return.

\subsubsection{Influence Return On Asset (ROA) to Stock Return}

One measure of profitability is Return On Assets. Where the company's ability to generate profits from the overall assets. From the investors' view, one important indicator to assess the prospects of development of the company in the future is to look at the extent to which the growth of the company's profitability.

According to Fahmi (2014) states that the Return On Invesmesten / Return On Asset ratio used to see the extent of the investments that have been implanted are able to provide returns as expected.

The higher return on assets higher the company's ability to generate profits, the higher the profits produced by the company will make the investors interested in the value of the stock. High Return On Asset that will attract investors to invest their capital to this company because they earned higher profit and will have an impact on the dividend to be received by investors. The more that are interested will create demand for the shares continue to rise, making the company's stock price will be an advanced riding as well.

These results are supported by research conducted by (Kindangen, 2016) concluded that the return on assets is partially significant effect on stock returns. And research conducted by Gd. Gilang Gunadi and (Kesuma, 2015) which concluded that the Return On Asset Significantly positive effect on stock return.

\subsubsection{Influence Earning Per Share (EPS) of the Stock Return}

Investors are not only oriented towards profit, but taking into account the level of risk which is owned by the company, if the investor decides to invest its equity in the company. The level of profit that can be generated per shares owned by investors against an issuer company performance. The higher the EPS value investors consider the company excellent prospects for the future that affect the level of demand for the company's stock price.

Shareholders and prospective investors in general will be interested in Earning Per Share (EPS), because EPS is one indicator of the success of a company. Earning Per Share (EPS) is the ratio of net profit before tax to the price per share. EPS shows how much profit given to the investors of each share owned. Simply put EPS describe the amount of money earned for each share.

Based on the success rate of the company, investors will pay attention to its influence in the future by looking at the company's prospects are good. Growth in earnings per share the company will be considered by investors in making investment decisions. If the stock price reflects the capitalization of earnings expected in the future, then the profit increase will boost the share price and total market capitalization.

According to Fahmi (2014) states that the earning per share or earnings per share is the form of the advantage given to the shareholders of each share owned. 
According to (Kasmir, no date) states that a low Earning Per Share means have not managed to satisfy shareholders, in contrast with the high ratio of shareholder wealth increases. In another sense pembalian a high level.

Earning Per Share means that the company will provide an opportunity rate of return or income large enough for investors. Therefore Earning Per Share are often used by investors as it reflects the level of income earned possibility of shareholders being spent.

These results are supported by research conducted by (Kesuma, 2015)which concluded that the Earning Per Share Significantly positive effect on stock return. And research conducted. And research conducted by (Widiawati, 2016)concluded that the Earning Per Share is Parsia significant effect on stock price.

\subsubsection{Effect of Debt to Equity Ratio (DER) of the Stock Return}

Debt to Equity Ratio concept DER measure how far the company's assets are financed from debt. Debt to Equity Ratio reflects the company's ability to meet its obligations through the capital itself. The higher the Debt to Equity Ratio is increasingly showing companies are increasingly at risk. The lower the Debt to Equity Ratio, the higher the company's ability to pay its obligations. The higher this ratio will show a poor performance for the company.

According (Kasmir, no date) that "DebtTo Equity Ratio is used to assess the debt for equity. Debt to Equity Ratio will affect the company's performance and cause share price appreciation. Debt to Equity Ratio is too high to have an adverse impact on the performance of the company, because of the higher debt levels signify the company's interest burden will be greater and reduces profits. So the higher the debt Debt to Equity Ratio tends to lower stock returns.

(Houston, 2010) states that "The higher the ratio Laverage represented by Debt to Equity Ratio. The greater the profit of the company ".

These results are supported by research conducted by (Anisa, 2015) concluded that the Debt to Equity Ratio partially significant effect on stock returns. However, research conducted by (Syeh, 2016) which concluded that the Debt to Equity Ratio Significantly negative effect on stock return.

\subsubsection{Influence Return On Assets, Earnings Per Share and Debt to Equity Ratio on Stock Return}

The share price is one indicator of the company management. The success in generating profits that will give satisfaction for a rational investor. The share price is high enough to be profitable, in the form of capital gains and a better image for the company, making it easier for management to obtain outside funding problems. In this case there are several factors that affect stock prices. one of which is Return on Assets (ROA), Earning Per Share (EPS) and Debt to Equity Ratio (DER).

According to Fahmi Irham (2014) states that the Return On Invesmesten / Return on assets is a ratio that is used to see the extent of the investments that have been implanted are able to provide returns as expected.

The higher return on assets higher the company's ability to generate profits, the higher the profits produced by the company will make the investors interested in the value of the stock.

The higher the value Earning Per Share of course encouraging shareholders for greater profits available for shareholders. Debt to Equity Ratio (DER) shows a comparison between the loan or debt and capital in the development of the company. If the Debt to Equity Ratio 
(DER) is high, there is the possibility of the company's stock price will be low because if the company makes a profit, companies tend to use the profits to pay its debts compared by dividing the dividend.

According(Zubir, 2011) The movement of stock prices rise and fall can earn profits and losses for investors. The stock price movements can be by the company's fundamentals of the company, the business environment, other economic indicators (such as interest rates), as well as stocks and Bid.

Research conducted by the gracious Princess Amelia Bahar (2012) stated that the Return on Assets, Earnings Per Share and Debt to equity ratio has a significant positive effect on stock returns.

\section{Research Methods}

The research approach used in this study is to use associative approach. Associative approach is the approach of using two or more variables in order to determine the relationship between variables or influence one another. This study uses secondary data and empirical, where the data obtained from the document by means of browsing on the official website of Indonesia Stock Exchange (BEI). Samples were taken using purposive sampling method to obtain 8 Company as samples from 48 populations. Data collection techniques performed by the engineering documentation. Data analysis technique using classical asumsu test (normality test, multicollinearity, and heteroscedasticity test), multiple linear regression was used as an analytical tool and to test the hypotheses used t-test, and the test of determination.

\section{Results And Discussions}

\subsection{Multiple Linear Regression Analysis}

In analyzing the data used multiple linear regression analysis. Where multiple analysis is useful to determine the effect of each independent variable on the dependent variable. This test is to determine whether the regression model used worthy (fit) for testing the hypothesis in this study. The test is performed by means of SPSS version 17.0.

Here are the results of data processing which shows linear regression analysis as dtunjukkan by Table 4.1 below:

Table 1. Results of Multiple Linear Regression Testing

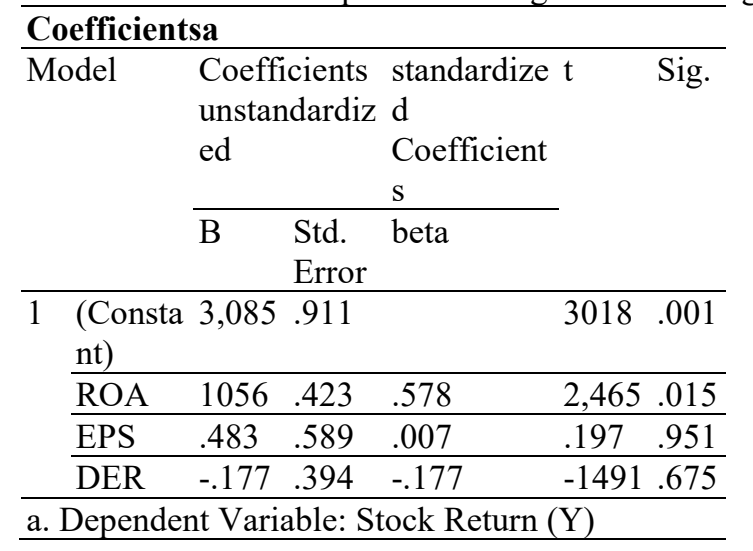


Results are incorporated into the multiple linear regression equation in order to know the following equation:

$\mathrm{Y}=3.085+1,056 \mathrm{X} 1+0,483 \mathrm{X} 2-0,177 \mathrm{X} 3$

Based on the multiple linear regression equation above, it is known:

1) The regression coefficient of ROA is 1.056 , which is positive. This value can be interpreted ROA have the direction of the positive influence on stock returns. Unknown Sig value $0.015<0.05$ and $3.018 \mathrm{t}>\mathrm{t}$ table 2.024 , the ROA significant effect on stock returns.

2) Regression coefficient value of EPS is 0,483 , which is positive. This value can be interpreted EPS have the direction of a positive influence on stock returns. Unknown Sig value $0.951>0.05$ and $0.197 \mathrm{t}<\mathrm{t}$ table 2.024, the EPS had no significant effect on stock returns.

3) DER value of the regression coefficient is -0.177 and negative. This value can be interpreted DER direction negative effect on stock returns. Unknown Sig value 0.675> 0.05 and $-1.491 \mathrm{t}<\mathrm{t}$ table 2.024, DER has no significant effect on stock returns.

\subsection{Hypothesis Testing}

\subsubsection{Partial Significance Tests}

The t-test used in this study to determine the ability of each independent variable in influencing the dependent variable. Reason $t$ test done is to test whether the independent variable (X) are individually significant relationship exists or not on the dependent variable (Y). Here are the results of data processing which shows linear regression analysis as dtunjukkan by Table 4.1 below:

Table 2:Partial Test Results

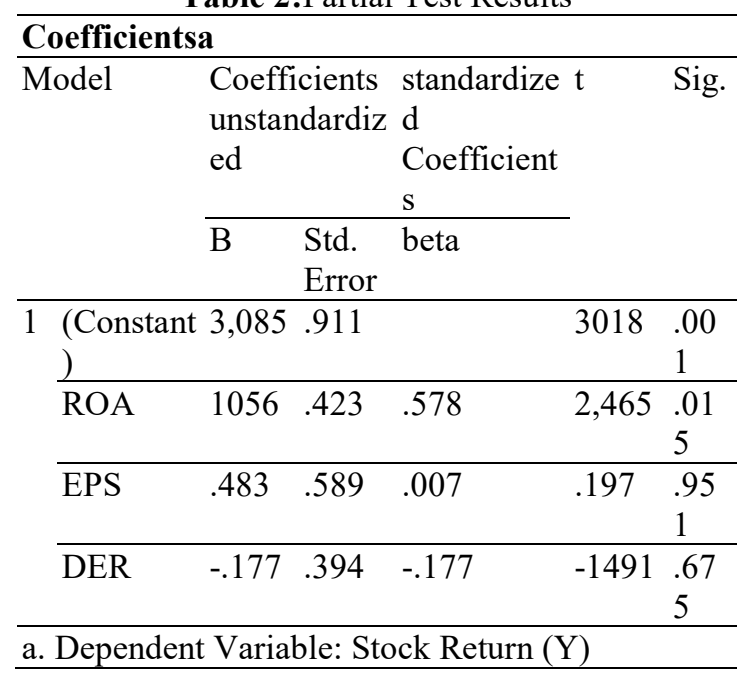

Statistical tests $t$ in the table above can be explained as follows:

1) Influence Return On Asset (ROA) Return on Equity. 
The t-test is used to determine whether the Return On Asset (ROA) effect individually (partial) had a significant relationship or not on Stock Return. For criteria t test conducted at the level of $\alpha=0.05$ with a value of $\mathrm{t}$ for $\mathrm{n}=40-2=38$ was 2,024 . for that $\mathrm{t}=2.465$ and $\mathrm{t}$ table $=2.024$.

Value $\mathrm{t}$ for variable Return On Asset (ROA) was 3,018 bigger than ttabel 2,024 $(0,305>2,024)$. Significance $(0015)$ is less than alpha $(0.05)$ (sig. $0.015<\alpha 0.05)$. Thus H0 Ha accepted and rejected. Conclusion: there is a positive and significant influence between the Return On Asset (ROA) Return on Equity.

2. Influence Earning Per Share (EPS) of the Stock Return.

The t-test is used to determine whether the Earning Per Share (EPS) effect individually (partial) had a significant relationship or not on Stock Return. For criteria t test conducted at the level of $\alpha=0.05$ with a value of $t$ for $n=40-2=38$ was 2,024 . for that $t=0.197$ and $\mathrm{t}$ table $=2.024$.

Tcount to Earning Per Share (EPS) for 0197 is smaller than ttabel $2024(0197 \leq 2,024)$ with significant (0951) Is greater than alpha (0.05) (sig.0951> A0.05). Thus H0 is accepted and Ha rejected. In conclusion: there is a significant positive influence and not between the Earning Per Share (EPS) of the Stock Return.

3. Effect of Debt to Equity Ratio (DER) of the Stock Return.

The t-test is used to determine whether the Debt to Equity Ratio (DER) effect individually (partial) had a significant relationship or not on Stock Return. For criteria $t$ test conducted at the level of $\alpha=0: 05$ with a value of $t$ for $n=40-2=38$ was 2,024 . for that $\mathrm{t}=-1.491$ and table $=2.024$.

$t_{\text {arithmetic }}$ for Debt to Equity Ratio (DER) of -1491 smaller than ttabel $2.024(-1.491 \leq$ 2.024) significantly (0675) is greater than alpha (0.05) (sig. 0675> $\alpha 0.05$ ). Thus H0 is accepted and $\mathrm{Ha}$ rejected. In conclusion: there is no significant negative effect and Turnover among the Debt to Equity Ratio (DER) of the Stock Return.

\subsubsection{Simultaneous Significance Tests}

$\mathrm{F}$ test is used to see whether the independent variables simultaneously have an influence on the dependent variable. To test the statistical hypothesis through F test conducted at the level of $\alpha=5 \%$ and the value of $F$ for $n=40$.Here's an $F$ on the test results data that has been processed using SPSS version 17.00.

Table 3. Simultaneous Test Results

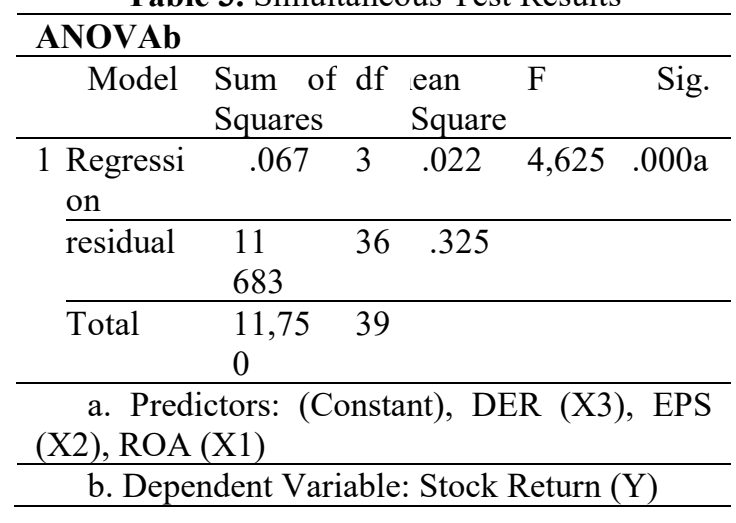


aor Ftabel $=\mathrm{n}-\mathrm{k}-1=40-3-1=36$ is equal to 2.87 .

Based on the test results the simultaneous influence of ROA, EPS, and DER simultaneously to Stock Return. Retrieved Fhitung value is 4, 625while Ftabel 2.87 and a significant level of value $0,000<0.05$. meaning that $\mathrm{H} 0$ is rejected and $\mathrm{Ha}$ accepted. Based on these results it can be concluded that the variable Return On Asset (ROA), Earning Per Share (EPS), and Debt to Equity Ratio (DER) has a significant influence on Stock Return to the company's Property and Real Estate listed on the Indonesia Stock Exchange (IDX) the period 2012-2016.

\subsubsection{Coefficient of Determination}

The coefficient of determination (R2) function to see the extent to which the overall independent variables can explain the dependent variable. Coefficient of determination grew stronger, which means independent variables provide almost all the information needed to predict the variation of the dependent variable. While the value of the determinant coefficient (adjusted R2) is small means that the ability of independent variables in explaining the variation of the dependent variable is limited.

Table 3: Coefficient of Determination

\begin{tabular}{|c|c|c|c|c|}
\hline \multicolumn{5}{|c|}{ Model Summaryb } \\
\hline Model & $\mathrm{R}$ & $\begin{array}{l}\mathrm{R} \\
\text { Square }\end{array}$ & $\begin{array}{l}\text { Adjusted } \\
\mathrm{R} \\
\text { Square }\end{array}$ & $\begin{array}{l}\text { Std. Error } \\
\text { of the } \\
\text { Estimate }\end{array}$ \\
\hline 1 & $.476 a$ & $0 \quad .33$ & .288 & 41.3142 \\
\hline \multicolumn{5}{|c|}{$\begin{array}{l}\text { a. Predictors: (Constant), DER (X3), EPS (X2), } \\
\text { ROA (X1) }\end{array}$} \\
\hline b. Depe & dent V & riable: $\mathrm{S}$ & ock Retur & \\
\hline
\end{tabular}

Based on the coefficient of determination in the above table, the value of R-Square above note worth $0.330 \%$. That is demonstrated that a 33\% variable Stock Return is determined by variableReturn on Assets (ROA), Earning Per Share (EPS), and Debt to Equity Ratio (DER), While the remaining $67 \%$ is influenced by other variables that are not included in this study

\subsection{Discussion}

\subsubsection{Influence Return On Asset (ROA) onStock Return}

The results obtained on the effect of the Return On Asset (ROA) to Stock Return in the Company Property and Real Estate listed on the Stock Exchange Indonesi showed that partially Return on Assets (ROA) has positive and not significant to the Stock Return to the company's Property and Real Estate listed on the Indonesia Stock Exchange (BEI).

The results of this study line in line with research conducted by Gd. Gilang Gunadi and I Ketut (Kesuma, 2015)which concluded that the Return On Asset Significantly positive effect on stock return.

\subsubsection{Influence Earning Per Share (EPS) onStock Return}

The results obtained on the effect of EPS on Stock Return on Property and Real Estate Company listed on the Indonesia Stock Exchange. EPS shows that partially positive and not 
significant to the Stock Return on Property and Real Estate companies listed in Indonesia Stock Exchange (BEI).

This is supported by research (Susilowati, 2011) which states that EPS does not have a significant impact on Stock Return, but not in line with research conducted by Rosdian Widiawati Watung and Ventje physical defect (2016) concluded that the earning per share is partially significant effect on Stock price.

\subsubsection{Effect of Debt to Equity Ratio (DER)onStock Return}

The results obtained on the effect of Debt to Equity Ratio (DER) of the Stock Return on Property and Real Estate Company listed on the Indonesia Stock Exchange. showed that partially Debt to Equity Ratio (DER) and no significant negative effect on Stock Return in Property and Real Estate companies listed in Indonesia Stock Exchange (BEI).

This is supported by research Tumonggor et al (2017) which states that Debt to Equity Ratio (DER) does not have a significant impact on Stock Return. These results are supported by research conducted by Nesa Anisa (2015) concluded that the Debt to Equity Ratio partially significant effect on stock returns. However, research conducted by Muhammad Sheikh (2016) which concluded that the Debt to Equity Ratio Significantly negative effect on stock return.

\subsubsection{Influence Return on Assets (ROA), Earning Per Share (EPS), and Debt to Equity Ratio (DER) on Stock Return}

The test results simultaneously shows that the Return On Asset (ROA), Earning Per Share (EPS), and Debt to Equity Ratio (DER) has a significant effect on Stock Return to the company's Property and Real Estate listed on the Indonesia Stock Exchange (BEI).

These results are consistent with research conducted byGraceful Princess Amelia Bahar (2012) stated that the Return on Assets, Earnings Per Share and Debt to equity ratio has a significant positive effect on stock returns.

\section{Conclusions}

Based on research results that have been obtained and the results of the analysis or discussion that has been presented in the previous chapter, it can diambi conclusions about InfluenceReturn on Assets (ROA), Earning Per Share (EPS), and Debt to Equity Ratio (DER) to Stock Return in Property and Real Estate companies listed in Indonesia Stock Exchange (BEI) in the year 2012 to 2016 as follows:

1. Based on research that has been done on the Property and Real Estate companies listed in Indonesia Stock Exchange (BEI) in 2012-2016, it can be concluded that there is significant influence betweenReturn on Assets (ROA) Return on Equity.

2. Based on research that has been done on the Property and Real Easate company listed on the Indonesia Stock Exchange (BEI) in 2012-2016, it can be concluded that there is no significant effect between Earning Per Share (EPS) Return on Equity.

3. Based on research that has been done on the Property and Real Estate companies listed in Indonesia Stock Exchange (BEI) in 2012-2016, it can be concluded that there is no significant effect between Debt to Equity Ratio (DER)Return on Equity.

4. Based on research that has been done on the Property and Real Estate companies listed in Indonesia Stock Exchange (BEI) in 2012-2016, it can be concluded that there 
significant influence between the Return on Assets (ROA), Earning Per Share (EPS), and Debt to Equity Ratio (DER) of the Stock Return.

\section{References}

[1] Anisa, N. (2015) 'analisis faktor-faktor yang mempengaruhi return saham (studi kasus pada perusahaan sub sektor AUTOMATIVE AND COMPONENTS yang terdaftar di bursa efek indonesia periode 2010-2014)', analisis faktor-faktor yang mempengaruhi return saham (studi kasus pada perusahaan sub sektor AUTOMATIVE AND COMPONENTS yang terdaftar di bursa efek indonesia periode 2010-2014), 1 No. 1.

[2] Fahmi, I. (2012) Manajemen Investasi Teori dan Soal Jawab. Jakarta: Salemba Empat.

[3] Hani, S. (2014) 'teknik analisa laporan keuangan', in teknik analisa laporan keuangan. medan: in media.

[4] Harmono (2009) 'manajemen keuangan berbasis balenced seorecard pendekatan teori kasus dan riset bisnis', in manajemen keuangan berbasis balenced seorecard pendekatan teori kasus dan riset bisnis. jakarta: Bumi aksara.

[5] Houston, brigham dan (2010) 'dasar-dasar manajemen keuangan', in dasar-dasar manajemen keuangan. kesebelas. Jakarta: Salemba Empat.

[6] Kasmir (no date) 'Pengantar Manajemen keuangan', in 2010. ke dua. jakarta: prenadamedia group.

[7] Kesuma, G. G. G. dan K. W. (2015) 'Pengaruh ROA, DER, EPS terhadap RETURN SAHAM perusahaan food and beverage', Pengaruh ROA, DER, EPS terhadap RETURN SAHAM perusahaan food and beverage, 4 No. 6.

[8] Kindangen, F. E. P. dan paulus (2016) 'pengaruh ROA, NPM, dan EPS terhadap RETURN SAHAM perusahaan makanan dan minuman yang terdaftar di BEI periode 2010-2014', pengaruh ROA, NPM, dan EPS terhadap RETURN SAHAM perusahaan makanan dan minuman yang terdaftar di BEI periode 2010-2014, 4 No. 4.

[9] Munawir (2010) 'analisa laporan keuangan', in analisa laporan keuangan. ke lima be. yogyakarta: liberty yogyakarta.

[10] Samsul, M. (2006) 'pasar modan dan manajemen portofolio', in pasar modan dan manajemen portofolio. Jakarta: Erlangga.

[11] Sinaga, P. (2014) 'teori portofolio dan analisa investasi', in teori portofolio dan analisa investasi. medan: Mitra.

[12] Sjahrial, D. (2008) 'manajemen keuangan', in manajemen keuangan. kedua. Jakarta: mitra wacana media.

[13] Susilowati (2011) 'Reaksi Signal Rasio Profitabilitas dan Rasio Solyabilitas terhadap Retrun saham', Reaksi Signal Rasio Profitabilitas dan Rasio Solyabilitas terhadap Retrun saham, 3 No. 1.

[14] Syahyunan (2015) 'analisis investasi', in analisis investasi. medan: usu press.

[15] Syeh, M. (2016) 'analisis faktor-faktor yang mempengaruhi retrun saham (kasus pada perusahaan manufaktur yang Go Public di BEI periode 2010-2013)', analisis faktorfaktor yang mempengaruhi retrun saham (kasus pada perusahaan manufaktur yang Go Public di BEI periode 2010-2013).

[16] Widiawati, R. (2016) 'pengaruh ROA, NPM dan EPS terhadap Harga Saham Perusahaan Perbankan di BEI periode 2011-2015', pengaruh ROA, NPM dan EPS terhadap Harga Saham Perusahaan Perbankan di BEI periode 2011-2015, 2.

[17] Zubir, Z. (2011) 'manajemen portofolio penerapannya dalam investasi saham', in manajemen portofolio penerapannya dalam investasi saham. Jakarta: Salemba Empat. 
